\title{
Evaluation of Measles Cases Admitted to Dr. Behçet Uz Pediatric Diseases and Surgery Training and Research Hospital
}

\author{
Dr. Behçet Uz Çocuk Hastalıkları ve Cerrahisi Eğitim ve Araştırma Hastanesine \\ Başvuran Kızamık Olgularının Değerlendirilmesi
}

\author{
Aybüke Akaslan Kara(ID), illknur Çağlar(iD ), Elif Kıymet(ID), Elif Böncüoğlu(iD), Süleyman Nuri Bayram(iD), illker Devrim(iD) \\ Clinic of Pediatric Infectious Diseases, Dr. Behçet Uz Pediatrics and Surgery Training and Research Hospital, İmir, Turkey
}

Cite this article as: Akaslan Kara A, Çağlar i, Kıymet E, Böncüoğlu E, Bayram SN, Devrim i. Evaluation of measles cases admitted to Dr. Behçet Uz pediatric diseases and surgery training and research hospital J Pediatr Inf 2021;15(2):e75-e79.

\section{Abstract}

Objective: Measles is an important, vaccine-preventable, and highly contagious viral disease. In recent years, cases of measles increased due to migration and vaccine hesitancy. In this study, we aimed to evaluate the clinical features of measles cases referred to our hospital

Material and Methods: In this study, we evaluated the demographic characteristics, vaccination status, and complications of patients diagnosed with measles, that applied to Behçet Uz Pediatric Diseases and Surgery Training and Research Hospital between March 1, 2019 and June 29,2019 . The data were retrospectively analyzed from patient files, medical records of patients, and data from the Ministry of Health Measles Case Study Form.

Results: Data of 38 patients with serum measles IgM positivity were collected during the study period. The mean age of the patients was 21 months ( 3 months-175 months). Of the patients, 57.8\% were under one year old. The total complication rate was $86.8 \%$ in our patients. The most common complication was pneumonia (71\%). No significant difference was observed in the development of pneumonia in children under one year and over one year. Of the patients $7.8 \%$ were not vaccinated due to vaccination rejection, $34.2 \%$ were not vaccinated or vaccination status was unknown.

Conclusion: Measles is still an important health problem due to its severe complications and high contagion rates. In order to prevent measles outbreaks, it is necessary to increase the vaccination rates in the society, increase the awareness of the healthcare personnel, take appropriate isolation measures in the hospitalized patients.

Keywords: Vaccine, maculopapular rash, measles
Öz

Giriş: Kızamık, bulaşıcılığı oldukça yüksek olup, aşıyla önlenebilen önemli bir viral hastalıktır. Son yıllarda göç ve aşı reddi nedeniyle kızamık vakalarında artış görülmektedir. Bu çalışmada, hastanemize başvuran kızamık olgularının klinik özelliklerinin değerlendirilmesi amaçlanmıştır.

Gereç ve Yöntemler: Bu çalışmada, 1 Mart 2019-29 Haziran 2019 tarihleri arasında Dr. Behçet Uz Çocuk Hastalıkları ve Cerrahisi Eğitim ve Araştırma Hastanesi'ne makülopapüler döküntü ile başvuran, kesin kızamık tanısı alan hastaların demografik özellikleri, aşılanma durumları ve komplikasyonları değerlendirildi. Veriler hasta dosyalarından, tıbbi kayıtlarından ve Sağlık Bakanlığı Kızamık Vaka İnceleme Formu verilerinden retrospektif olarak incelendi.

Bulgular: Çalışma periyodu boyunca serum kızamık IgM pozitifliği saptanan 38 hastanın verileri toplandı. Hastaların yaş ortalaması 21 ay (3 ay-175 ay) olarak bulundu. Hastaların \%57.8'si bir yaş altı idi. Hastalarımızda toplam komplikasyon gelişme oranı \%86.8'di. En sık görülen komplikasyon pnömoni (\%71) olarak saptandı. Bir yaş altı ve bir yaş üstü çocuklarda pnömoni gelişmesi açısından anlamlı fark gözlenmedi. Hastaların \%7.8'i aşı reddi nedeniyle aşılanmamıştı, \%34.2' si ise aşısız ya da aşılanma durumu bilinmiyordu.

Sonuç: Kızamık, ağır komplikasyonlara yol açması ve yüksek bulaşıcılık oranlarına sahip olmasından dolayı halen önemli bir sağlık sorunudur. Kızamık salgınlarının önlenmesi için toplumdaki aşılanma oranlarının arttııı ması ek olarak sağlık personelinin farkındalığının artırııması, yatırılan hastalarda uygun izolasyon önlemlerinin alınması gerekmektedir.

Anahtar Kelimeler: Aşı, makülopapüler döküntü, kızamık

\author{
Correspondence Address/Yazışma Adresi \\ Aybüke Akaslan Kara \\ Dr. Behçet Uz Çocuk Hastalıkları \\ Eğitim ve Araştırma Hastanesi, \\ Çocuk Enfeksiyon Hastalıkları Kliniği, \\ İzmir-Türkiye \\ E-mail: aybukeakaslan@hotmail.com
}




\section{Introduction}

Measles is an infectious disease of the childhood period with high morbidity and mortality, whose agent is a negative single-stranded RNA virus of the Paramyxoviridae family and Morbillivirus species (1). Humans are the only known host, and the virus is transmitted essentially by respiratory droplets and more rarely by tiny aerosols that can remain suspended in the air for a long time.

Measles symptoms emerge 7-14 days after contact with the virus. Signs of prodromal disease include fever, cough, common cold, conjunctivitis, and Koplik spots. The measles rash, maculopapular in character, usually appears on the face at the hairline and spreads downward to the trunk and extremities and may become joined together. Individuals with measles are accepted infective throughout four days prior to the start of the rash and four days after the rash is gone. Complication risk is higher in children aged under five years, in persons aged over 20 years, and in patients with an underlying disease weakening the immune system. Frequently seen complications are otitis and diarrhea. Severe complications are pneumonia and encephalitis (2).

Although measles is a vaccine-preventable disease, it is still an important cause of morbidity and mortality in the world. According to the data of World Health Organization (WHO), a total of 401.024 measles cases were reported from regions of America, Africa, Europe, Eastern Mediterranean, and Western Pacific between January 2019 and August 2019 (3). Again, as regards WHO data, 89.994 measles cases were reported in the first half of the year 2019 from 48 countries of Europe (4). WHO reported 2.391 measles cases in Turkey for the year 2019 (4). This number was 716 in 2018, 69 in 2017, and 9 in 2016 (46). Yearly health statistics report of the Ministry of Health of Turkey has shown that measles incidence in our country was 0.01 in 100.000 population in 2016, 0.09 in 2017, and 0.87 in 2018 (7).

The inclusion of measles vaccination into the routine immunization program has ensured the decrease in measles cases and prolonged the periods between outbreaks. However, with the decrease in vaccination rates in recent years, there has been a marked increase in measles cases in the world and in our country. In this study, it was aimed to establish the clinical features, prognosis, and prognosis-related risk factors of measles cases that presented to our hospital.

\section{Materials and Methods}

In this study, the demographic characteristics of patients, aged under 18 years, presenting with maculopapular rash to Behçet Uz Pediatric Diseases and Surgery Training and Research Hospital between March 1, 2019 and June 29, 2019 and diagnosed with measles were retrospectively reviewed.
Suspect case was defined as cases with maculopapular rash; probable case (clinical case) as those compatible with clinical definition; and confirmed/true case as those confirmed with laboratory tests or those with epidemiological association. Clinical definition was made as fever higher than $38^{\circ} \mathrm{C}$ and disease characterized with maculopapular rash and cough/runny nose/conjunctivitis (8).

Laboratory diagnosis of measles was made by detecting measle virus-specific IgM antibodies through the ELISA method in patient serums in the National Measles Laboratory Unit of Microbiology Reference Laboratory Department of Public Health Institution of Turkey.

Data were obtained from patient files and medical records of the cases that had received measles diagnosis and from the Measles/Rubella Case Study Form of the Ministry of Health.

Age, sex, vaccination status, symptoms, and complications of the patients diagnosed with measles were evaluated. All patients were urgently reported to İzmir Infectious Diseases Branch by having the Measles/Rubella Case Examination Form of the Ministry of Health and Form 014 filled out, and post-contact measures were taken.

The study was approved by the Clinical Research Ethics Committee of Behçet Uz Pediatric Diseases and Surgery Training and Research Hospital.

\section{Results}

Forty-eight patients determined as suspect case and presenting with maculopapular rash to Behçet Uz Pediatric Diseases and Surgery Training and Research Hospital between March 1, 2019 and June 29, 2019 were evaluated. Among these patients, 38 were included into the study by being serum measles IgM positive.

All patients presenting to hospital and conforming to clinical definition were admitted for outbreak control regardless of complication status. Mean length of hospital stay was found as 5.2 days (2-12 days). Out of the 38 children included into the study, 19 were girls (50\%) and 19 were boys (50\%), and age distribution varied between 3 to 175 months. Mean age was found as 21 months. Considering age distribution, there were 22 patients at the age of $0-12$ months (57.8\%), 14 patients at the age of $1-5$ years (36.8\%), and two patients over the age of five years (5.2\%).

When route of infection was questioned, it was found out that 30 children (79\%) had come from the same county of Izmir and that they lived in discommodious conditions due to migration and had history of contact to one another. This situation was urgently reported to Izmir Infectious Diseases Branch. With the aid of Izmir Infectious Diseases Branch, the persons our cases got into contact with were vaccinated considering their age group or immunoglobulin support was given. 
While fever and rash were observed in all patients, these symptoms were accompanied by cough in 35 patients (92\%), runny nose in 17 patients (44\%), and conjunctivitis in 26 patients $(68 \%)$. Koplik spots were not seen in any of our patients. Leucopenia, lymphopenia, and neutropenia were seen in $6(15.7 \%), 5(13 \%)$, and $3(7.9 \%)$ patients, respectively, but thrombocytopenia was not seen in any. When patient presentation was reviewed in terms of months, it was found that 3 patients (7.9\%) presented in March, 14 (36.8\%) in April, 20 $(52.6 \%)$ in May and $1(2.6 \%)$ in June.

When vaccination rates of the patients diagnosed with measles were assessed, 22 of them (57.8\%) were underaged to get the vaccination according to the immunization calendar of the Ministry of Health and three were not vaccinated due to vaccination rejection. The remaining 13 patients (34.2\%) were unvaccinated or their vaccination status was unknown. Considering an underlying disease, none of the patients, except one with Down syndrome, had a previously known disease.

Total complication development rate in our patients was $86.8 \%$. Pneumonia, which is the most common complication, was seen in 27 patients (71\%). Six (22.2\%) of the 27 patients

Table 1. Characteristics and complications of measles cases

\begin{tabular}{|l|c|}
\hline Girl/Boy rate, $\mathrm{n}(\%)$ & $19 / 19(50 / 50)$ \\
\hline Mean age & 21 month \\
\hline Age (year), $\mathrm{n}(\%)$ & $22(57.8)$ \\
$<1$ & $14(36.8)$ \\
$1-5$ & $2(5.2)$ \\
$>5$ & \\
\hline Vaccination status, $\mathrm{n}$ (\%) & $22(57.8)$ \\
Underaged for routine immunization & $3(7.8)$ \\
Vaccination rejection & $13(34.2)$ \\
Unvaccinated or vaccination status unknown & \\
\hline Complications, $\mathrm{n}$ (\%) & $9(23.5)$ \\
Diarrhea\& & $27(71)$ \\
Pneumonia & $6(22.2)$ \\
HFNC need & $1(2.6)$ \\
Otitis & $1(2.6)$ \\
Keratitis & $1(2.6)$ \\
Hepatitis & \\
\hline HFNC: High flow nasal cannula. & \\
\&: Accompanying pneumonia in six patients. & \\
\hline
\end{tabular}

developing pneumonia required high-flow nasal cannula support, and of these patients, $3(50 \%)$ were aged under one year and the other $3(50 \%)$ were aged 1-5 years. Sixty percent of the cases followed with pneumonia diagnosis were aged under 1 year; however, a significant difference was not detected in terms pneumonia development in children under and over the age of 1 year ( $p>0.05)$. Chest X-ray of all patients that developed pneumonia was consistent with viral pneumonia, and interstitial involvement was seen. Other complications that patients developed were diarrhea in 9 (23.5\%), acute otitis media in $1(2.6 \%)$, keratitis in $1(2.6 \%)$, and hepatitis in 1 (2.6\%). All patients were discharged with full recovery. Table 1 shows the clinical features and complications of our patients. Table 2 expresses age distribution of the patients developing complications.

The patient suffering from keratitis was a 14-year-old boy who presented with pain, redness in the eye, and blurred vision that developed one day after the onset of rash. Bilateral central corneal epithelial keratitis foci were detected and cured without sequela with supportive treatment.

The patient whom we followed for liver involvement was a 17-month-old girl whose complaints were fever and rash on presentation. Blood tests revealed AST: 4.989 IU/L (5-40 IU/ LT), ALT: 3168 IU/L (10-40 IU/LT), and INR: 2.03 (0.8-1.2). The patient who did not have any signs of hepatic encephalopathy recovered without sequela with $\mathrm{N}$-acetyl cysteine infusion and Vitamin $\mathrm{K}$ treatment.

Vitamin A was given to all patients that fit the clinical case definition regardless of the risk factors. Vitamin A was administered orally as single dose daily for two days with the following dosages: $50.000 \mathrm{IU}$ for those under the age of 6 months, 100.000 IU for those between 6-11 months of age, and $200.000 \mathrm{IU}$ for those at the age of 12 months and over (9).

\section{Discussion}

This study evaluated 38 patients in whom serum measles IgM positivity was detected between March 1, 2019 and June 29 , 2019. Majority aged under one year made up $10 \%$, and $41 \%$ of the patients were found to be over the age of 20 years. In a study conducted in our country between the years 2013 and 2014 , majority of the patients (55\%) were over the age of five years, and contrary to our study, the rate of cases under

Table 2. Evaluation of patients developing complications according to age distribution

\begin{tabular}{|l|c|c|c|c|}
\hline Age (year) & Pneumonia & Diarrhea\& & Otitis & Keratitis \\
\hline$<1$ & $(60 \%)$ & $6(66.6 \%)$ & 1 & 1 \\
\hline$>1$ & $11(40 \%)$ & $3(33.3 \%)$ & 1 & 1 \\
\hline \multicolumn{2}{|l}{} \\
\hline
\end{tabular}


the age of one year was found as $25 \%$ (10). In a study from Italy evaluating 249 children diagnosed with measles between January 2016 and August 2017, 37.7\% of the cases were aged under one year and $21.1 \%$ were aged over five years (11).

Standard testing recommended by WHO for measles diagnosis is the detection of specific IgM antibodies by the ELISA method (12). This method was used in our study to confirm measles diagnosis. As of the onset of rashes, IgM positivity for measles is detected in the first two days in $70 \%$ of the cases and in 3-5 days in $90 \%$ of the cases. Following a peak within 7-10 days, IgM antibodies start to fall and can be rarely detected at the end of 6-8 weeks. IgG antibody levels peak at the third week and remain and are found long after the infection (12).

Symptoms such as cough, high fever, fatigue, sore throat, photophobia, nausea-vomiting, diarrhea, and myalgia are commonly seen in the prodromal phase of measles. Rash, conjunctivitis, Koplik spots, and lymphadenopathy are detected during the disease phase (9). Compatible with the literature, high fever, rash, and cough were determined most commonly in our patients. Being pathognomic, Koplik spots disappear 12-18 hours after the onset of rash (13). Since all of our patients presented with rash, Koplik spots were not seen in any of them.

It is known that measles causes temporary immunosuppression through the loss of lymphocyte precursors and functional deterioration of B or T lymphocytes and cells offering antigens (14). The number of both lymphocytes and neutrophil may drop; however, this situation only lasts a week. In this study, leucopenia was seen in six patients (15.7\%), and thrombocytopenia did not occur. In various studies, leucopenia and thrombocytopenia have been detected at a rate of $40-50 \%$ (11-15) and 4-16\% (11-16), respectively.

Measles is a mild to moderate disease. Complication rate can reach $40 \%$. In our study, total complication development rate was $86.8 \%$. Measles complications are encountered more in children aged under 1 year and in adults. Common complications of the disease are diarrhea (8\%), otitis media (7-9\%), and pneumonia (1-6\%) (17). Case/fatality rate is higher in infants and younger children. Complications mostly occur in the respiratory system, and pneumonia is mainly responsible for measles-related mortality. The most common complication in our study was pneumonia (27 patients, $71 \%$ ). A statistical difference was not found in pneumonia rates in children aged under one year and over one year. In a study retrospectively reviewing 20 cases between 2013 and 2014, one or more than one complication was determined in $70 \%$ of the patients, and pneumonia was the most common complication found (78.5\%), which was similar to our study (10). In a study by Metin et al. evaluating 44 measles cases, complication rate has been found as $18 \%$, and half of the complications have been observed as pneumonia and half as dehydration. Low number of complications in their study is thought to be due to the fact that these researchers have not considered diarrhea (10 patients) and otitis (four patients) as complications (18). In another study, the most common complications, similar to ours, have been found as pneumonia (23.3\%), followed by diarrhea $(22.9 \%)$, otitis $(7.2 \%)$, and hepatitis (6\%) (11). All patients included in our study were discharged with full recovery. According to 2019 data of WHO, a total of 37 measles-related deaths, three from Turkey, were reported. Fifty-four percent of these deaths were reported in children aged under 10 years (4).

Measles is a disease that is possible to eliminate since the only host is humans. In order to eradicate the disease, at least $95 \%$ of the community need to be immunized against the disease. Therefore, it is crucial to keep vaccination rates high so as not to have outbreaks. To that end, WHO has prepared and put into effect many measles elimination programs since 1989. Most recently, the Measles-Rubella Initiative prepared a strategic plan covering the period between 2012 and 2020. The purpose was to eliminate measles disease in six WHO regions until the end of 2020 and provide at least $95 \%$ protection with second routine measles vaccination doses (19). Regarding yearly health statistics report of the Ministry of Health, measles vaccination rate was detected as $96 \%$ in 2018 (7). According to WHO 2019 data for the European region, vaccination status of $70 \%$ of the patients diagnosed with measles was known, $62 \%$ of those were unvaccinated, and $21 \%$ of those were aged under one year (4). In a study from Italy evaluating 249 children diagnosed with measles between January 2016 and August 2017, single dose vaccination rate has been found as $10.8 \%$ and double dose as $0.8 \%$ (11). Measles vaccination in our country during the duration of this study was routinely performed at the $12^{\text {th }}$ month; however, due to increased measles cases afterwards, as an additional control strategy to outbreak control strategies conducted within the scope of Measles Elimination Program, it was decided to administer an additional measles vaccination dose to all infants aged over 9 months and under 12 months and to repeat the routine vaccination dose when they turned 12 months. Considering the vaccination status of our study, while $57.8 \%$ of the patients were underaged according to the immunization calendar of the Ministry of Health, $7.8 \%$ were unvaccinated due to vaccination rejection and the rest of our patients were unvaccinated or their vaccination status was unknown. Unfortunately, vaccinated cases were not present in our study.

\section{Conclusion}

To conclude, measles continues to be a significant cause of morbidity and mortality affecting susceptible individuals at every age. Pediatricians must be attentive in terms of measles complications, especially pneumonia in children, and it 
should also be kept in mind that complications may also develop without an underlying disease.

Ethics Committe Approval: Study protocol was approved by the Local Ethics Committee of Dr. Behçet Uz Children Diseases and Surgery Training and Research Hospital.

Informed Consent: Patient consent was obtained.

Peer-review: Externally peer-reviewed.

Author Contributions: Concept - All of authors; Design - All of authors; Supervision - All of authors; Resource - All of authors; Data Collection and/or Processing - All of authors; Analysis and/ or Interpretation - All of authors; Literature Search - All of authors; Writing - All of authors; Critical Review - All of authors.

Conflict of Interest: All authors declare that they have no conflicts of interest or funding to disclose.

Financial Disclosure: The authors declared that this study has received no financial support.

\section{References}

1. Gershon AA. Measles virus (Rubeola). In: Mandell GL, Bennett JE, Dolin $R$ (eds). Mandell, Douglas and Bennett's Principles and Practice of Infectious Diseases. $7^{\text {th }}$ ed. Churchill Livingstone, Philadelphia 2010:2229-36. [CrossRef]

2. Centers for Disease Control and Prevention (CDC). Measles. Available from: https://www.cdc.gov/measles/symptoms/index.html [CrossRef]

3. World Health Organization (WHO). Measles. Available from: https:// www.who.int/immunization/monitoring_surveillance/burden/vpd/ surveillance_type/active/measles_monthlydata/en [CrossRef]

4. World Health Organization (WHO). A report on the epidemiology of selected vaccine-preventable diseases in the European Region no:2 12019. Available from: http://www.euro.who.int/_data/assets/pdf_ file/0017/410714/EpiBrief_2_2019_EN.pf?ua=1 [CrossRef]

5. World Health Organization (WHO). A report on the epidemiology of selected vaccine-preventable diseases in the European Region no:2/2017. Available from: http://www.euro.who.int/ data/assets/ pdf_file/0006/349062/EpiBrief_2_2017_EN-2.pdf?ua=1 [CrossRef]

6. World Health Organization (WHO). A report on the epidemiology of selected vaccine-preventable diseases in the European Region no:1/2018. Available from: http://www.euro.who.int/ data/assets/ pdf_file/0009/370656/epibrief-1-2018-eng.pdf?ua=1 [CrossRef]
7. T.C. Sağlık Bakanlığı Sağlık Bilgi Sistemleri Genel Müdürlüğü. Sağlık Istatistikleri Yıllığı 2018 Haber Bülteni, 2019. [CrossRef]

8. T.C. Sağlık Bakanlığı Halk Sağlığı Genel Müdürlüğü. Kızamık Eliminasyon Programı. Available from: https://hsgm.saglik.gov.tr/dosya/ mevzuat/genel_nitelikli_yazilar/asi_db/kizamik_eliminasyon_programi_67643.pdf [CrossRef]

9. American Academy of Pediatrics. Red Book. Report of the Committee on Infectious Diseases, 31 ${ }^{\text {st }} \mathrm{ed}$. 2018-2021:540-1. [CrossRef]

10. Türkkan ÖN, Önal ZE, Sağ Ç, Akıcı N, Gürbüz T, Nuhoğlu Ç. Kızamık olgularımızın demografik özellikleri, hastalığın morbidite ve mortalitesinin değerlendirilmesi. Haydarpasa Numune Med J 2017;57(2):83-8. [CrossRef]

11. Lo Vecchio, Andrzej KR, Carlotta M, Piero V, Nadia R, Silvia G, et al. Complications and risk factors for severe outcome in children with measles. Arch Dis Child 2020;105(9):896-9. [CrossRef]

12. Ulusal Mikrobiyoloji Standartları (UMS). Kızamık ve SSPE'de (Subakut Sklerozan Panensefalit) Mikrobiyolojik Tanı 2015. Available from: http://mikrobiyoloji. thsk.saglik.gov.tr/Dosya/tani-rehberi/viroloji/ UMS-V-MT-08-Kizamik-ve-SSPE.pdf [CrossRef]

13. Gershon AA. Measles virus (Rubeola), In: Mandell GL, Bennett JE, Dolin $R$ (eds), Mandell, Douglas and Bennett's Principles and Practice of Infectious Diseases. $7^{\text {th }}$ ed. Churchill Livingstone, Philadelphia. 2010:222936. [CrossRef]

14. Avota E, Gassert E, Schneider-Schaulies S. Measles virus-induced immunosuppression: from effectors to mechanisms. Med Microbiol Immunol 2010;199:227-37. [CrossRef]

15. Kuşçu F, Öztürk DB, Gül S, Karagöz E, Suntur B, Ünlü B, et al. Bir kızamık salgını esnasında kliniğimizce takip edilen erişkin kızamık olgularının değerlendirilmesi. KÜ Tıp Fak Derg 2014;16(3):12-6. [CrossRef]

16. Filia A, Bella A, Del Manso M, Baggieri M, Magurana F, Rota MC. Ongoing outbreak with well over 4,000 measles cases in Italy from January to end August 2017 - what is making elimination so difficult? Euro Surveill 2017;22:30614 [CrossRef]

17. Centers for Disease Control and Prevention (CDC). Gastañaduy PA, James L. Goodson Measles (rubeola). Travelers' Health. Available from: https://wwwnc.cdc.gov/travel/yellowbook/2020/travel-related-infectious-diseases/measles-rubeola [CrossRef]

18. Metin Ö, Tanır G, Öz FN, Kalaycıoğlu A, Yolbakan S, Tuygun N, et al. Evaluation of 44 pediatric measles cases detected in Ankara, Turkey during 2012-2013 epidemic and molecular characterization of the viruses obtained from two cases. Mikrobiyol Bul 2014;48:259-70. [CrossRef]

19. Orenstein WA, Hinman A, Nkowane B, Olive JM, Reingold A. Measles and rubella global strategic plan 2012-2020 midterm review. Vaccine 2018;36:A1-A34. [CrossRef] 